\title{
Congenital myasthenic syndrome caused by a frameshift insertion mutation in GFPT1
}

Szabolcs Szelinger, PhD, Jonida Krate, BS, Keri Ramsey, BSN, Samuel P. Strom, PhD, Perry B. Shieh, MD, PhD, Hane Lee, PhD, Newell Belnap, BS, Chris Balak, BS, Ashley L. Siniard, BS, Megan Russell, BS, Ryan Richholt, BS, Matt De Both, BS, Ana M. Claasen, BS, Isabelle Schrauwen, PhD, Stanley F. Nelson, MD, PhD, Matthew J. Huentelman, PhD, David W. Craig, PhD, Samuel P. Yang, MD, Steven A. Moore, MD, PhD, Kumaraswamy Sivakumar, MD, Vinodh Narayanan, MD, and Sampathkumar Rangasamy, PhD, on behalf of UCLA Clinical Genomics Center

Neurol Genet 2020;6:e468. doi:10.1212/NXG.0000000000000468

\section{Abstract}

\section{Objective}

Description of a new variant of the glutamine-fructose-6-phosphate transaminase 1 (GFPT1) gene causing congenital myasthenic syndrome (CMS) in 3 children from 2 unrelated families.

\section{Methods}

Muscle biopsies, EMG, and whole-exome sequencing were performed.

\section{Results}

All 3 patients presented with congenital hypotonia, muscle weakness, respiratory insufficiency, head lag, areflexia, and gastrointestinal dysfunction. Genetic analysis identified a homozygous frameshift insertion in the GFPT1 gene (NM_001244710.1: c.686dupC; p.Arg230Ter) that was shared by all 3 patients. In one of the patients, inheritance of the variant was through uniparental disomy (UPD) with maternal origin. Repetitive nerve stimulation and single-fiber EMG was consistent with the clinical diagnosis of CMS with a postjunctional defect. Ultrastructural evaluation of the muscle biopsy from one of the patients showed extremely attenuated postsynaptic folds at neuromuscular junctions and extensive autophagic vacuolar pathology.

\section{Conclusions}

These results expand on the spectrum of known loss-of-function GFPT1 mutations in CMS12 and in one family demonstrate a novel mode of inheritance due to UPD.

\author{
Correspondence \\ Dr. Rangasamy \\ srangasamy@tgen.org
}

From theNeurogenomics Division (S.S., J.K., K.R., N.B., C.B., A.L.S., M.R., R.R., M.D.B., A.M.C., M.J.H, V.N., S.R.), Translational Genomics Research Institute, Center for Rare Childhood Disorders, Phoenix, AZ; Fulgent Genetics (S.P.S.), Temple City, CA; Department of Neurology (P.B.S.), University of California Los Angeles; David Geffen School of Medicine (P.B.S.), Los Angeles; Department of Pathology and Laboratory Medicine (H.L., S.F.N.), University of California, Los Angeles; Department of Human Genetics (H.L., S.F.N.), David Geffen School of Medicine; Department of Neurology (I.S.), Columbia University, Center for Statistical Genetics, New York; Department of Translational Genomics (D.W.C.), University of Southern California, Los Angeles; Providence Sacred Heart Medical Center and Children's Hospital (S.P.Y.), Spokane, WA; Department of Pathology (S.A.M), University of lowa, Carver College of Medicine; and Neuromuscular Clinic and Research Center (K.S.), Phoenix, AZ.

Go to Neurology.org/NG for full disclosures. Funding information is provided at the end of the article.

The Article Processing charge was funded by TGen Foundation. 


\section{Glossary}

C4RCD = Center for Rare Childhood Disorders; CMS = congenital myasthenic syndrome; GFPT1 = glutamine-fructose-6phosphate transaminase 1; LCRH = long contiguous regions of homozygosity; NEB = nebulin; NMJ = neuromuscular junction; RNS = repetitive nerve stimulation; SMA = spinal muscular atrophy; TA = tubular aggregate; UPD = uniparental disomy; WES $=$ whole-exome sequencing.

Congenital myasthenic syndrome (CMS) is a genetically and clinically heterogeneous group of disorders with compromised neuromuscular transmission. Common underlying symptoms are fatigable skeletal muscle weakness confined to the ocular, bulbar, or limb-girdle muscles. ${ }^{1}$ Classification of CMS is based on inheritance pattern and localization of defects at the neuromuscular junction (NMJ). ${ }^{1,2}$ To date, over 30 genes have been identified to cause CMS, which are functionally critical for the development and maintenance of $\mathrm{NMJ}{ }^{3,4}$ Mutations in genes involved in the N-linked glycosylation pathway have also been identified to cause CMS. Genetic linkage analysis and whole-exome sequencing (WES) experiments have identified biallelic mutations in the gene encoding glutamine-fructose-6-phosphate transaminase 1 (GFPT1, Online Mendelian Inheritance in Man [OMIM]: 138292) as the cause of CMS type 12 (OMIM:610524). GFPT1 enzyme converts fructose-6-phosphate to glucosamine-6-phosphate through a rate-limiting transamidase reaction that regulates the biosynthesis of $\mathrm{N}$-acetylglucosamine and protein glycosylation. ${ }^{2,5}$ Most of the biallelic GFPT1 gene mutations that cause CMS12 are missense, nonsense, or frameshift with protein truncation, and also a recurrent $3^{\prime}$ untranslated region mutation has also been reported. ${ }^{2,5,6}$ Patients with GFPT1 mutation display characteristic symptoms such as limb-girdle weakness and tubular aggregates (TAs) in skeletal muscle fibers. ${ }^{5}$ Patients also show evidence of decremental response to repetitive nerve stimulation (RNS), indicating NMJ dysfunction. ${ }^{7}$ In this study, we present clinical, neurophysiologic, histopathologic, and genetic findings in 2 unrelated families with 3 affected children diagnosed with CMS12 who share the same loss-of-function GFPT1 variant. This report expands on current knowledge of the effects of pathogenic GFPT1 variants.

\section{Methods}

\section{Standard protocol approvals, registrations, and patient consents}

Family A was enrolled in the research protocol at the Center for Rare Childhood Disorders (C4RCD). The protocol was reviewed and approved by the Western Institutional Review Board (Protocol \#20120789). Informed consent for sequencing and data usage was obtained from each participant or their guardian for children younger than the age of 18. Patient A1 had clinical evaluation at C4RCD. Patients from family B were evaluated at the Department of Neurology, The University of California, Los Angeles (patient B1), and Providence Medical Group (patient B2).

\section{Whole-exome sequencing}

Patient A1 had trio WES and analysis at TGen. Sequence data were analyzed using in-house-developed pipeline that included alignment, quality filtering, single nucleotide variant and indel calling, copy number analysis, variant annotation, and filtering. ${ }^{8}$ The annotated variant list was filtered using genetic models including de novo, homozygous recessive, compound heterozygous, and $\mathrm{X}$-linked. Candidate variants were prioritized based on population frequency, in-silico predictions, and clinical phenotype. Candidate variants were validated by Sanger sequencing.

Patient B1 had clinical WES at The University of California, Los Angeles Clinical Genomics Center as a singleton. ${ }^{9}$ Patient B2 underwent targeted GFPT1 gene sequencing by Pacific Biosciences.

\section{Neurophysiologic studies}

Nerve conduction, EMG, and repetitive stimulation studies were performed on patient A1. Patient B1 had single fiber $\mathrm{EMG}$ on the left extensor digitorum communis.

\section{Data availability}

Variant level data will be submitted and made available in ClinVar.

\section{Results}

\section{Clinical history}

\section{Family A, patient A1}

This is a 11-year-old Hispanic girl with severe muscle weakness since birth. She was born at term by emergency C-section because of fetal heart rate irregularities. She required bag-mask ventilation, was electively intubated, and required mechanical ventilation. A gastrostomy tube was placed at 1 month of age. Physical examination revealed severe hypotonia, weakness, decreased spontaneous movement, and areflexia. At 5 months of age, she demonstrated severe head lag with hypotonia. Fluctuating responses were seen with deep tendon reflexes. An examination at 2.5 years revealed significant diffuse hypotonia, severe muscle weakness, facial diplegia, minimal to no movement of her shoulders and proximal legs, flabby muscles, severe head lag, and hyporeflexia. She had severe scoliosis, requiring the use of a neck collar and thoracic brace. Based on her EMG findings (figure 1), she was treated with pyridostigmine and had a partial response. At 3 years of age, she underwent tracheostomy and was treated with 3,4-diaminopyridine together with pyridostigmine. The addition of 3,4-diaminopyridine did not result in significant clinical 


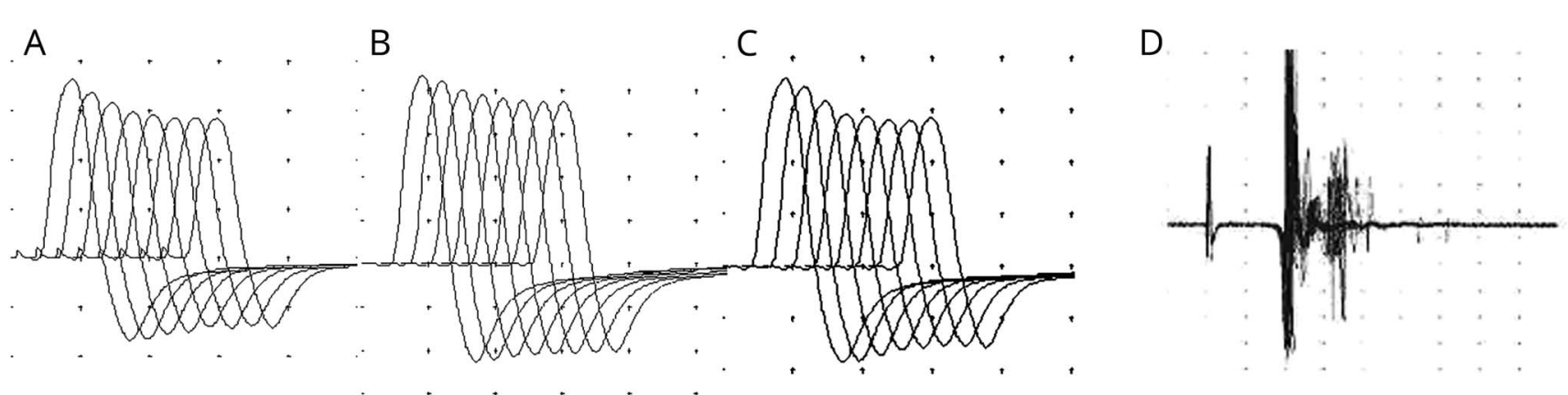

Decremental response on $3 \mathrm{~Hz}$ repetitive nerve stimulation of hand muscle of patient A showing a postjunctional neuromuscular deficit by postactivation facilitation and then exhaustion; decrement of $13 \%$ at rest (A), $7 \%$ immediately after 30 seconds exercise (B), and $15 \%$ at 360 seconds after the exercise (C). Stimulated (15 c/s) single-fiber EMG study on extensor digitorum communis muscle on patient B1 demonstrating a large jitter on the last unit (D).

improvement and was discontinued because of changes in her ECG. There was no family history of muscle disorders, and both parents were unaffected. Previous molecular testing included a chromosomal microarray, which revealed 2 long contiguous regions of homozygosity (LCRH) of 57.6, and 89.8 Mbases on chromosome 2p21q11.2 and 2q22.1q36.3, respectively. Genetic testing was negative for spinal muscular atrophy (SMA), PraderWilli syndrome, congenital myotonic dystrophy, and the genes linked to CMS known before year 2010 (table 1). Targeted testing for SURF1, SCO1, SCO2, and COX10 mutations was negative.

\section{Family B, patient B1}

This is an 8-year-old boy of Mexican ancestry with congenital hypotonia, low muscle bulk, dysphagia requiring gastrostomy tube feeding, recurrent respiratory infections, and with a tracheostomy. He was born at 39 weeks gestation to a 34-year-old G9 P7 mother via vaginal delivery after an uncomplicated pregnancy. At initial evaluation, he was noted to be floppy, with a sluggishly reactive left pupil. He eventually underwent gastrostomy tube placement and tracheostomy and needed mechanical ventilation. At 1 month, he was found to have bilateral cryptorchidism, micrognathia, a high arched palate without evidence of cleft, head lag, marked decrease in proximal tone, and absent deep tendon reflexes. At 10 months of age, he weighed $3.6 \mathrm{~kg}$ and was bright and alert. There was minimal spontaneous movement, minimal movement of the arms, and no movement of the legs at all. He slipped through at the shoulders on vertical suspension and had a severe head lag. Tone was slightly better in

Table 1 Variants associated with CMS and ruled out

\begin{tabular}{|c|c|c|c|c|c|c|c|c|c|}
\hline Patient & GT & HGNC & HGVS.C & HGVS.p & SIFT & Polyphen & Consequence & $\begin{array}{l}\text { gnomAD } \\
\text { MAF (\%) }\end{array}$ & Note \\
\hline B1 & $\begin{array}{l}0 / \\
1\end{array}$ & $N E B$ & c. $18660 \mathrm{G}>\mathrm{C}$ & p.Leu6220Phe & Tolerated & Benign & Missense & 0.02925 & Comp het \\
\hline B1 & $\begin{array}{l}0 / \\
1\end{array}$ & $N E B$ & c. $5696 C>T$ & p.Thr1899lle & Tolerated & $\begin{array}{l}\text { Probably } \\
\text { damaging }\end{array}$ & Missense & 0.04445 & Comp het \\
\hline B1 & $\begin{array}{l}0 / \\
1\end{array}$ & CHRND & c. $117 C>G$ & p.Asn39Lys & Tolerated & Benign & Missense & 0.5509 & $\begin{array}{l}\text { High population } \\
\text { frequency }\end{array}$ \\
\hline B1 & $\begin{array}{l}0 / \\
1\end{array}$ & $L A M B 2$ & c. $4751 A>G$ & p.Glu1584Gly & Tolerated & Benign & Missense & 0.00041 & $\begin{array}{l}\text { Het for autosomal } \\
\text { recessive disorder }\end{array}$ \\
\hline A1 & $\begin{array}{l}0 / \\
1\end{array}$ & MUSK & c. $2553 \mathrm{~T}>\mathrm{A}$ & p.Ser851Arg & Deleterious & $\begin{array}{l}\text { Possibly } \\
\text { damaging }\end{array}$ & Missense & - & - \\
\hline A1 & $\begin{array}{l}0 / \\
1\end{array}$ & CHAT & c. $1682 \mathrm{G}>\mathrm{A}$ & p.Arg561Gln & Tolerated & $\begin{array}{l}\text { Probably } \\
\text { damaging }\end{array}$ & Missense & 0.75 & - \\
\hline A1 & $\begin{array}{l}0 / \\
1\end{array}$ & RAPSN & c. $614 \mathrm{G}>\mathrm{A}$ & p.Arg205Gln & Tolerated & Benign & Missense & 1.585 & $\begin{array}{l}\text { High population } \\
\text { frequency }\end{array}$ \\
\hline A1 & $\begin{array}{l}0 / \\
1\end{array}$ & SCN4A & c. $404 \mathrm{~T}>\mathrm{C}$ & p.Met135Thr & Tolerated & Benign & Missense & 0.15 & - \\
\hline
\end{tabular}

Abbreviations: CMS = congenital myasthenic syndrome; comp het = compound heterozygous; GT = genotype; HGNC = HUGO Gene Nomenclature Committee; HGVS.c = Human Genome Variation Society coding DNA reference sequence position; HGVS.p = HGVS protein reference sequence position; $\mathrm{MAF}=$ minor allele frequency; $N E B=$ nebulin; SIFT = Sorting Intolerant from Tolerant. 
the legs than the arms. At the age of 2 years, he was able to breathe on his own, requiring intermittent mechanical ventilation during hospitalizations for respiratory infections. At the age of 8 years, he wore a neck brace and thoracolumbosacral orthosis. He had a tracheostomy tube, ate pureed food by mouth, and received supplemental nutrition by G-tube. The patient had normal speech and intelligence and attended 2 nd grade in a special needs school. His medications included budesonide, cholecalciferol, guar gum, levalbuterol, and docusate. He started 3,4-diamnopyridine at the age of 8 years, without benefit. Previous molecular testing included a normal karyotype, negative testing for Prader-Willi, SMA, and congenital myotonic dystrophy. Enzymatic and metabolic assays for creatine kinase, thyroid function, serum cortisol, plasma ammonia, quantitative amino acid profile, very long chain fatty acids, pyruvate, lactate, and acylcarnitine profile were all normal.

\section{Family B, patient B2}

This boy is the younger sibling of patient B1, and he died at the age of 2 years. He was born at 37-1/2 weeks of gestation after a pregnancy complicated by gestational diabetes and hypertension. He was intubated immediately after delivery and required resuscitation with chest compression. In the neonatal intensive care unit, he was started on a therapeutic hypothermia protocol for presumed hypoxic-ischemic encephalopathy. On initial evaluation, EEG was abnormal (presumably because of hypothermia) but showed no evidence of seizures and improved after rewarming. Echocardiogram and renal ultrasound were normal. Head ultrasound revealed grade 1 germinal matrix hemorrhage, and brain MRI showed left germinal matrix and intraventricular hemorrhage. He had a broad nasal bridge, ptosis, micrognathia, a tented upper lip, high and narrow palate, slightly wide set nipples, and descended testes. He also had loose skin on his neck and around his thighs. His torso appeared long, and there was a limitation of elbow extension to approximately $150^{\circ}$, and he had diffusely decreased muscle tone and absent tendon reflexes. Some benefit from pyridostigmine treatment was observed.

\section{Neurophysiologic findings}

\section{Clinical neurophysiology}

\section{Patient A1}

Nerve conduction studies at the age of 2 years revealed low compound muscle action potentials, especially in the trapezius and facial muscles. EMG showed rapid recruitment of motor units suggestive of a myopathy. There was no spontaneous activity in limb muscles. A $13 \%$ decremental response to $3 \mathrm{~Hz}$ RNS was seen only in the hand muscles and not in the trapezius muscle. At the age of 6 years, the RNS revealed postactivation facilitation and postexercise exhaustion suggestive of a postsynaptic NMJ defect (figure 1, A-C).

\section{Patient B1}

At 10 months, a reproducible decrement of $18 \%$ was seen on RNS of the left abductor pollicis brevis muscle. At the age of 6 years, RNS demonstrated a $14 \%$ decremental response of abductor pollicis minimi and a 39\% decremental response on the trapezius. Radial nerve-stimulated single-fiber EMG of the left extensor digitorum communis muscle demonstrated a dramatically increased variability of latency (jitter) in 11 pairs of the 14 pairs tested, with an average mean consecutive difference value of 165.5 microseconds (normal <36.6) and blocking seen in 8 pairs of 14 total tested, suggesting a disorder of neuromuscular transmission (figure 1D).

\section{Muscle biopsy}

\section{Patient A1}

A quadriceps muscle biopsy performed at 1 month of age was nondiagnostic. No residual tissue was available for further evaluation including electron microscopy after the genetic diagnosis.

\section{Patient B1}

A left quadriceps muscle biopsy at the age of 1 month showed a population of abnormally small muscle fibers that was suggestive of a myopathy. No residual tissue was available for further evaluation after genetic diagnosis.

\section{Patient B2}

Light microscopy and transmission electron microscopy revealed a mild necrotizing myopathy with extensive autophagic vacuolar pathology (figure 2A). Autophagic vacuoles had sarcolemmal features in that acetylcholinesterase was localized at the surface of cytoplasmic vacuoles (figure $2 \mathrm{~B}$ ). Extrusion of autophagic vacuoles from affected muscle fibers was noted (figure 2C). Intramuscular nerve twigs seemed normal in cryosections (not shown) and in electron micrographs (figure 2D). By contrast, NMJs had varying degrees of postsynaptic fold attenuation (figure 2, E-H), whereas synaptic vesicles were numerous within nerve terminals. Complete absence of NMJ end plate folds was noted in association with some nerve terminals (figure $2 \mathrm{H}$ ). No TAs were observed.

\section{Genetic findings}

\section{Patient A1}

An average of $61 \mathrm{X}$ coverage was obtained in the trio exomes. Previous chromosomal microarray data suggested that uniparental disomy (UPD) of chromosome 2 and that pathogenic homozygous variants on chromosome 2 may contribute to the patient's symptoms. Copy number and homozygosity analysis of the exome data confirmed the copy neutral long contiguous stretches of homozygosity reported by array comparative genomic hybridization (A 3). A homozygous, frameshift insertion was discovered in GFPT1 at 2p13.3 (chr2:69581443insG; NM 001244710.1:c.686dupC; p.Arg230Ter) (figure 3). This variant is at the $5^{\prime}$ end of exon 9, adjacent to the splice acceptor site of the muscle/heart specific transcript (NM_001244710), and results in the introduction of a termination codon. The variant was observed in the mother as a heterozygous change, whereas the father was a homozygous reference, suggesting UPD. These 

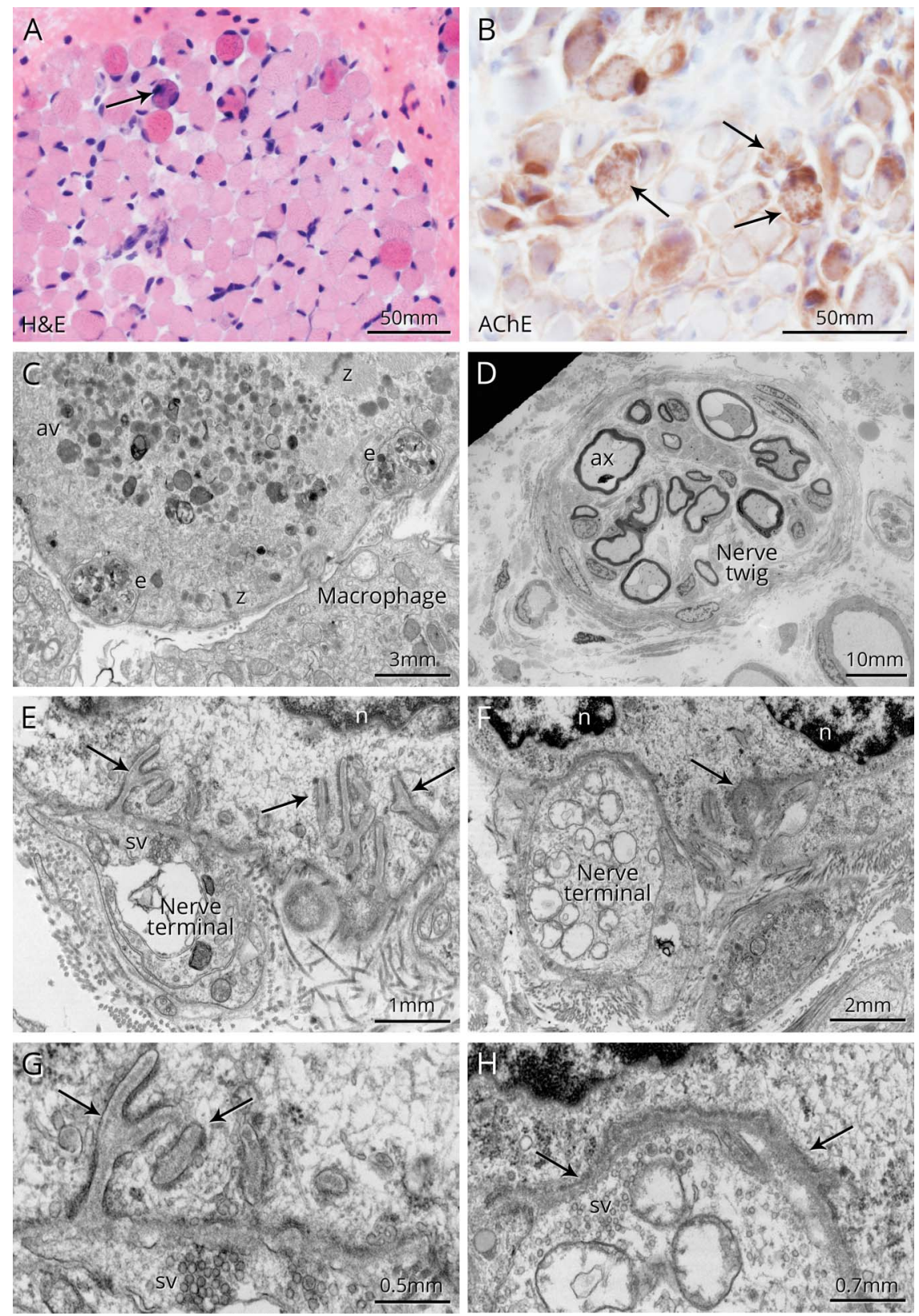

The cryosection H\&E image (A) shows increased variation in fiber size and a mild degree of regeneration (arrow), suggesting that the patient has a mild, necrotizing myopathy. AChE enzyme histochemistry (B) highlights numerous cytoplasmic autophagic vacuoles with sarcolemmal features (arrows). Extensive autophagy is confirmed by electron microscopy (C). av occupy most of the intracellular space of the muscle fiber in the upper portion of the micrograph. Only rare sarcomeres are present, as noted by $2 \mathrm{Z}$ lines $(z)$ in this image. Extrusion of autophagic vacuoles $(E)$ is evident at the surface of this muscle fiber. Intramuscular nerve twigs appear normal (D). Two of numerous NMJs observed in the biopsy are illustrated in panels $(\mathrm{E}-\mathrm{H})$. There are varying degrees of postsynaptic fold attenuation (arrows), milder in panels $E$ and $G$ and complete loss of NMJ endplate folds in panels $F$ and $\mathrm{H}$. Nerve terminals contain numerous sv. Portions of muscle fiber nuclei are present along the top of panels $E, F$, and $H(n)$. AChE = acetylcholinesterase; $a v=$ autophagic vacuoles; $\mathrm{H} \& \mathrm{E}=$ hematoxylin \& eosin; NMJ = neuromuscular junction; sv = synaptic vesicles.

findings were independently confirmed by Sanger sequencing and confirmed loss of the paternal chromosome 2 segment (figure 4, A and B). This variant is observed in a single individual $(1 / 219894)$ as a heterozygous change in the gnomAD v2.1.1 database. ${ }^{10}$ In-silico predictions suggested that GFPT1 is intolerant to loss-of function variation (Exome Aggregation Consortium probability of being loss-of-function intolerant = 0.97). There are 10 GFPT1 variants in ClinVar, in patients with CMS12, classified as pathogenic or likely pathogenic, which include missense, stop gained, and frameshift indels (table 2). Evaluation of the known genes associated with CMS revealed that Patient Al was heterozygous for variants in CHAT, MUSK,
RAPSN, and SCN4A that were ruled out because of insufficient evidence for pathogenicity using American College of Medical Genetics criteria. ${ }^{11}$ There were no additional candidates outside the region of LCRH found to correlate with the patient's symptoms.

\section{Patient B1}

An average of $154 \mathrm{X}$ coverage was obtained for this singleton WES. Variants of uncertain clinical significance were identified in nebulin (NEB), SH3T2C, POLG, and GFPT1 genes. After clinical correlation, potential compound heterozygous variants in the gene (NEB, OMIM:161650) were reported. ${ }^{9}$ 


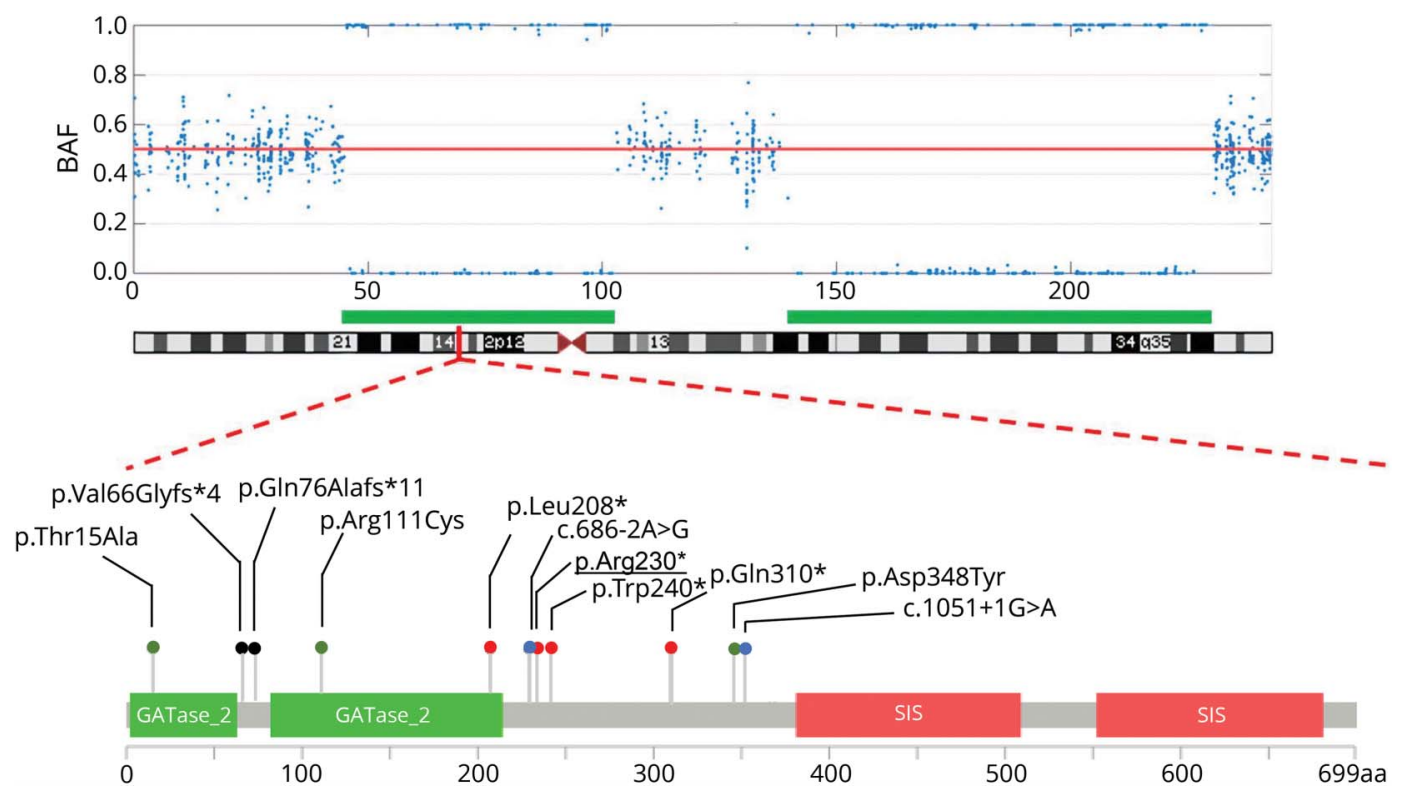

BAF plot from WES of patient A1 (top) demonstrates long continuous regions of homozygosity (blue dots with BAF $\sim 1$ or BAF $\sim 0$ ) that overlaps with previous array CGH data (green horizontal bars). Red, vertical bar at 2p13.3 on the cytoband indicates the position of GFPT1 gene within the LCRH. Below the cytoband, domain structure of GFPT1 and ClinVar pathogenic and likely pathogenic mutations in relation to GFPT1 domains of NM_001244710 and to p.Arg230* (underlined) identified in this study. Variants are colored based on their functional impact $(\mathrm{green}=$ missense, black $=$ frameshift, red $=$ nonsense, and blue $=$ splice). BAF = B allele frequency; $\mathrm{CGH}=$ comparative genomic hybridization; $G F P T 1=$ glutamine-fructose-6-phosphate transaminase 1; LCRH = long contiguous regions of homozygosity; SIS = sugar isomerase domain; WES = whole-exome sequencing.

$N E B$ is associated with autosomal recessive nemaline myopathy type 2 (OMIM: 256030) which carries similar features to CMS but is also associated with nemaline rods. ${ }^{12}$ Parents were not available to determine phase of the 2 NEB variants. Reanalysis of exome data was requested, and the GFPT1 p. Arg230Ter variant was reclassified as likely pathogenic. Other CMS-related variants were also identified in CHRND and $L A M B 2$ but were ruled out per American College of Medical Genetics guidelines.

\section{Patient B2}

Sequencing in the patient and his parents using congenital myopathy gene panel testing (Pacific Biosciences, Menlo Park, CA) identified the same p.Arg230Ter homozygous variant in $\mathrm{B} 2$ and demonstrated that both parents were heterozygous.

\section{Discussion}

We report the first case of maternal UPD of chromosome 2 in CMS and with a novel loss-of-function variant in GFPT1 and provide support for pathogenicity of this variant by describing another family with CMS sharing the same variant. These 3 patients, from 2 unrelated families, with similar clinical phenotypes further expand the clinical spectrum of CMS12. Other CMS-related genetic variants were excluded in these families (table 1). From a clinical perspective, all patients presented with the classic clinical features of CSM12, including hypotonia, general muscle weakness, little to no movement of shoulders and proximal legs, feeding difficulty, and EMG decrement in 2 of the 3 patients (table 3 ). However, they also share symptoms not commonly observed in CMS12. All of them manifested with respiratory insufficiency that required ventilator support at one point which is mostly associated with DOK7 or RAPSN deficiency. ${ }^{13}$ Although CMS12 usually manifests within the first decade of life, only a few cases have been reported with congenital onset. ${ }^{5}$ Here, all 3 patients manifested with clinical symptoms at birth. In fact, 2 patients previously reported with early onset of disease carried splice altering variants at the muscle specific exon 9 junction and predicted biallelic loss of GFPT1, suggesting that loss-offunction variants confined to the muscle and heart-specific transcript adversely affects muscle fiber integrity and may result in earlier onset and a more severe clinical course. ${ }^{14,15}$

Although the addition of 3,4-diaminopyridine to pyridostigmine treatment resulted in a positive response in one of the patients with GFPT1 mutation (B2), it did not improve symptoms in Patient A1 or B1, indicating heterogeneity in response to the drug treatment. Selcen et al. ${ }^{14}$, reported a female patient with nonambulatory status, requiring respiratory support and a G-tube, harboring a nonsense and a splicealtering variant; her muscle biopsy demonstrated autophagic vacuolar pathology and attenuation of NMJ end plate folds, similar to the findings in the most severely affected (patient B2) of our children and absence of a $\sim 70 \mathrm{kd}$ glycoprotein. Muscle biopsies from many of the reported CMS12 cases have shown 
A

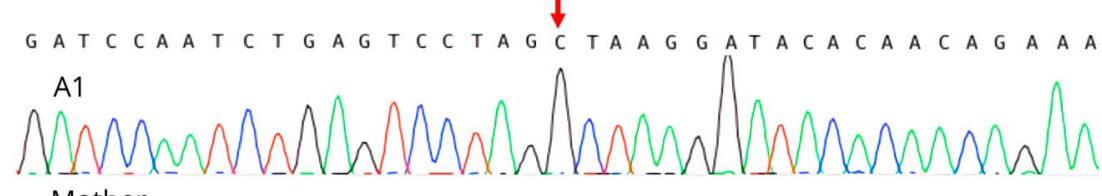

Mother

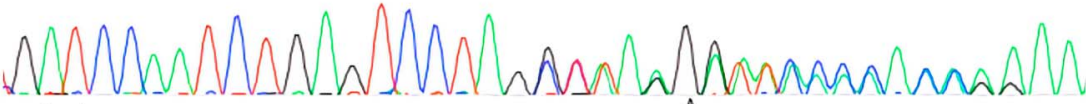
Father

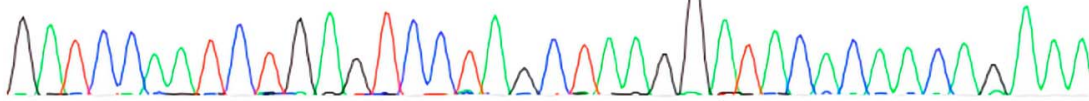

B1

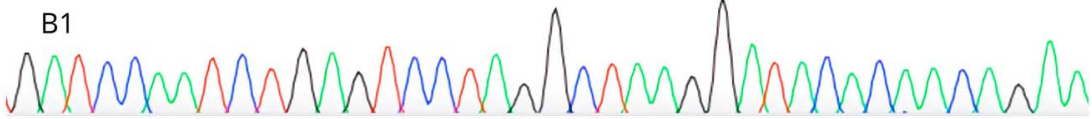

B

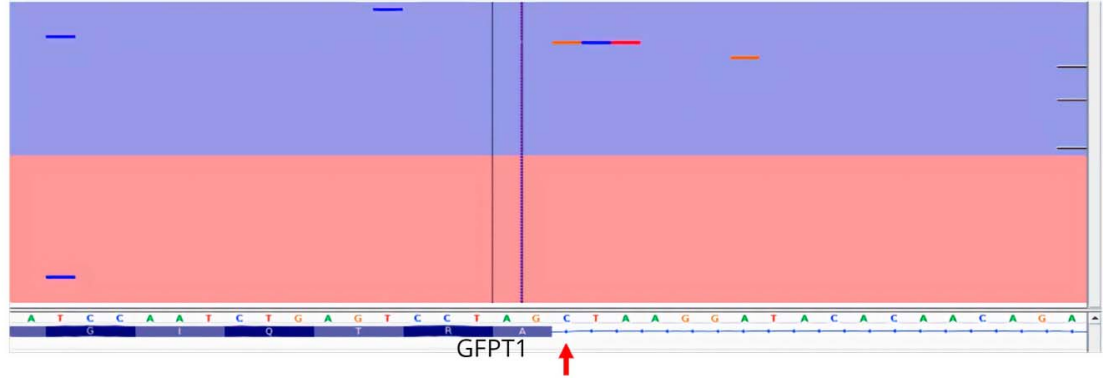

(A) Sanger sequencing-confirmed exome sequencing findings for members of family $A$ and for patient B1 with the red arrow indicating the frameshift insertion. Mother is heterozygous indicated by the overlapping peaks, whereas father was homozygous reference. (B) PacBio sequence traces showing patient B2 homozygosity. GFPT1 = glutamine-fructose-6-phosphate transaminase 1 .
TAs, leading to the term congenital myasthenic syndrome with tubular aggregates ${ }^{5}$ None of our patients demonstrated TAs on histopathologic studies.
The p.Arg230Ter variant has not been described before in patients with CMS12 and is predicted to result in loss of GFPT1 protein in muscle and heart cells. ${ }^{16}$ Although this

Table 2 Clinvar pathogenic GFPT1 variants in CMS12 based on ClinVar release date April 29, 2020

\begin{tabular}{|c|c|c|c|}
\hline HGVS.C & HGVS.p & Pubmed ID & Clinvar variant ID \\
\hline NM_002056.4:c.1051+1G>A & a & 23794683 & 540351 \\
\hline NM_002056.4:C.1042G>T & p.Asp348Tyr & 21310273 & 29738 \\
\hline NM_002056.4:C.928C>T & p.Gln310Ter & 28492532 & 570975 \\
\hline NM_001244710.2:c.964C>T & p.Arg322Ter & 23794683 & 859066 \\
\hline NM_001244710.1:c.719G>A & p.Trp240Ter & 21310273 & 29737 \\
\hline NM_002056.4:c.621del & p.Leu207_Leu208insTer & 21310273 & 29740 \\
\hline NM_002056.4:C.452C>A & p.Thr151Lys & 30635494 & 631478 \\
\hline NM_001244710.1:C.331C>T & p.Arg111Cys & $21310273 \mid 8664562$ & 29735 \\
\hline NM_001244710.1:c.223dupA & p.Gln76Alafs $11^{a}$ & 21310273 & 29736 \\
\hline NM_002056.3:c.197_201delTTAAG & p.Val66Glyfs $4^{a}$ & 28492532 & 583230 \\
\hline NM_001244710.1:c.43A>G & p.Thr15Ala & $12467753 \mid 12467753$ & 29739 \\
\hline NM_002056.4:c.41G>T & p.Arg14Leu & 30635494 & 631477 \\
\hline NM_001244710.1:c.686-2A>G & a & $28464723 \mid 237944683$ & 540353 \\
\hline
\end{tabular}

Abbreviations: CMS = congenital myasthenic syndrome; GFPT1 = glutamine-fructose-6-phosphate transaminase 1.

a Splice mutation. 
Table 3 Clinical summary of patients with GFPT1 mutations

\begin{tabular}{|c|c|c|c|c|c|}
\hline Patient ID or publication source & A1 & B1 & B2 & (Ref 15) & (Ref 14) \\
\hline Sex & Female & Male & Male & Male & Female \\
\hline Mutation (HGVS.c) & c.686dupC/a & $\begin{array}{l}\text { c.686dupC/ } \\
\text { c.686dupC }\end{array}$ & $\begin{array}{l}\text { c.686dupc/ } \\
\text { c.686dupC }\end{array}$ & $\begin{array}{l}\text { c. } 686-2 A>G / c .686- \\
2 A>G\end{array}$ & $\begin{array}{l}\text { c. } 686-2 A>G / \\
\text { c. } 910 C>T\end{array}$ \\
\hline APGAR & $5,6,6$ & $1,6,7$ & $1,2,5$ & & \\
\hline Generalized muscle weakness & b & $\mathrm{b}$ & $\mathrm{b}$ & & \\
\hline Ambulation & a & a & & $\mathrm{b}$ & a \\
\hline Hypotonia & $\mathrm{b}$ & b & b & a & b \\
\hline Head lag/muscle weakness & $\mathrm{b}$ & $\mathrm{b}$ & $\mathrm{b}$ & $\mathrm{b}$ & \\
\hline Areflexia & $\mathrm{b}$ & $\mathrm{b}$ & $\mathrm{b}$ & & \\
\hline $\begin{array}{l}\text { Prominent neck flexor } \\
\text { weakness }\end{array}$ & b & b & & b & b \\
\hline Scoliosis & Severe $^{\mathrm{b}}$ & a & a & Mild $^{\mathrm{b}}$ & \\
\hline Muscle atrophy & $\mathrm{b}$ & $\mathrm{b}$ & & b & \\
\hline Pes cavus deformity & & & & a & \\
\hline Ocular/facial/bulbar weakness & Facial diplegia & $\mathrm{b}$ & $\mathrm{b}$ & a & $\mathrm{b}$ \\
\hline Myopathy & $\mathrm{b}$ & $\mathrm{b}$ & $\mathrm{b}$ & $\mathrm{b}$ & $\mathrm{b}$ \\
\hline Muscular dystrophy & & & & $\mathrm{b}$ & $\mathrm{b}$ \\
\hline Respiratory insufficiency & b & $\mathrm{b}$ & Transient & a & \\
\hline Pneumonia & $\mathrm{b}$ & $\mathrm{b}$ & & & \\
\hline Mechanical ventilation & $\mathrm{b}$ & $\mathrm{b}$ & $\mathrm{b}$ & a & $\mathrm{b}$ \\
\hline Gastrointestinal dysfunction & G-tube ${ }^{b}$ & G-tube ${ }^{b}$ & G-tube ${ }^{b}$ & a & G-tube ${ }^{b}$ \\
\hline Cardiovascular irregularities & b & & & a & \\
\hline
\end{tabular}

Abbreviations: APGRA = appearance, pulse, grimace, activity, and respiration; HGVS.c = Human Genome Variation Society coding DNA reference sequence position.

${ }^{a}$ Not observed. Empty cells indicate no information.

b Observed.

genetic variant is shared among all 3 of the described children, the variation in severity and spectrum of symptoms suggest pathophysiologic complexity. To the best of our knowledge, patient A1 is the first instance of maternal UPD of chromosome 2, homozygosity for the GFPT1 nonsense mutation located within the UPD region, inherited from a mother who was heterozygous for the pathogenic GFPT1 variant. Glycosylation deficiency is one of the causes of CMS, and mutations have been identified in several glycosylation pathway genes including DPAGT1, ALG2, ALG14, and GFPT1. ${ }^{5,17,18}$ The exact mechanism by which glycosylation deficiency causes the NMJ defect is still unclear. Loss of GFPT1 protein can result in abnormal glycosylation in muscle cells, reduced acetylcholine receptor cell surface expression, and abnormal sialylation of transmembrane muscle proteins. ${ }^{14,19,20}$ Electrophysiologic studies in one of our children who had UPD and predicted loss of function of the GFPT1, suggesting a postsynaptic NMJ defect. Reduction in GFPT1 induces structural changes in the end plate characterized by loss of junctional folds and denervation-reinnervation process affecting NMJ. ${ }^{19}$ However, the molecular consequences of absence of the ubiquitously expressed GFPT1 protein is not fully understood. This report expands the clinical, genetic, histologic and electrophysiologic spectrum of GFPT1 gene mutations related CMS12.

\section{Acknowledgment}

The authors would like to thank the families and patients for their participation in this study.

\section{Study funding}

This study was supported by private donations to the TGen Foundation and to TGen's Center for Rare Childhood Disorders (C4RCD). S.A. Moore is partially funded by the Iowa Wellstone Muscular Dystrophy Cooperative Research Center, U54, NS053672, from NIH.

\section{Disclosure}

S. Szelinger, J. Krate, and K. Ramsey report no disclosures. S.P. Storm is an employee and shareholder of Fulgent Therapeutics LLC, a for-profit genetics laboratory; he has no other 
disclosures. P.B. Shieh, S.P. Yang, S.A. Moore, H. Lee, N. Belnap, C. Balak, A.L. Siniard, M. Russell, R. Richholt, M.D. Both, A.M. Claasen, I. Schrauwen, S.F. Nelson, M.J. Huentelman, D.W. Craig, K. Sivakumar, V. Narayanan, and S. Rangasamy report no disclosures. Go to Neurology.org/NG for full disclosures.

\section{Publication history}

Received by Neurology: Genetics May 22, 2019. Accepted in final form May 26, 2020.

Appendix 1 Authors

\begin{tabular}{|c|c|c|}
\hline Name & Location & Contribution \\
\hline $\begin{array}{l}\text { Szabolcs } \\
\text { Szelinger, PhD }\end{array}$ & $\begin{array}{l}\text { Translational } \\
\text { Genomics Research } \\
\text { Institute }\end{array}$ & $\begin{array}{l}\text { Acquisition of data, data } \\
\text { analysis, data } \\
\text { interpretation, manuscript } \\
\text { writing, and review }\end{array}$ \\
\hline Jonida Krate, BS & $\begin{array}{l}\text { Translational } \\
\text { Genomics Research } \\
\text { Institute }\end{array}$ & $\begin{array}{l}\text { Acquisition of data, data } \\
\text { analysis, data } \\
\text { interpretation, manuscript } \\
\text { writing, and review }\end{array}$ \\
\hline $\begin{array}{l}\text { Keri Ramsey, } \\
\text { BSN }\end{array}$ & $\begin{array}{l}\text { Translational } \\
\text { Genomics Research } \\
\text { Institute }\end{array}$ & $\begin{array}{l}\text { Acquisition of data, data } \\
\text { analysis, data } \\
\text { interpretation, and } \\
\text { manuscript review }\end{array}$ \\
\hline $\begin{array}{l}\text { Samuel P. } \\
\text { Strom, PhD }\end{array}$ & Fulgent Genetics & $\begin{array}{l}\text { Data analysis, data } \\
\text { interpretation, and } \\
\text { manuscript review }\end{array}$ \\
\hline $\begin{array}{l}\text { Perry B Shieh, } \\
\text { MD, PhD }\end{array}$ & $\begin{array}{l}\text { University of California } \\
\text { Los Angeles }\end{array}$ & $\begin{array}{l}\text { Acquisition of data, data } \\
\text { analysis, data } \\
\text { interpretation, and } \\
\text { manuscript review }\end{array}$ \\
\hline $\begin{array}{l}\text { Samuel P. Yang, } \\
\text { MD }\end{array}$ & $\begin{array}{l}\text { Providence Sacred } \\
\text { Heart Medical Center } \\
\text { and Children's Hospital }\end{array}$ & $\begin{array}{l}\text { Acquisition of data, data } \\
\text { analysis, data } \\
\text { interpretation, manuscript } \\
\text { writing, and review }\end{array}$ \\
\hline $\begin{array}{l}\text { Steven A. } \\
\text { Moore, MD, PhD }\end{array}$ & University of lowa & $\begin{array}{l}\text { Acquisition of data, data } \\
\text { analysis, data } \\
\text { interpretation, manuscript } \\
\text { writing, and review }\end{array}$ \\
\hline Hane Lee, PhD & $\begin{array}{l}\text { University of California } \\
\text { Los Angeles }\end{array}$ & $\begin{array}{l}\text { Data analysis, data } \\
\text { interpretation, and } \\
\text { manuscript review }\end{array}$ \\
\hline $\begin{array}{l}\text { Newell Belnap, } \\
\text { BS }\end{array}$ & $\begin{array}{l}\text { Translational } \\
\text { Genomics Research } \\
\text { Institute }\end{array}$ & $\begin{array}{l}\text { Data analysis, data } \\
\text { interpretation, manuscript } \\
\text { review }\end{array}$ \\
\hline Chris Balak, BS & $\begin{array}{l}\text { Translational } \\
\text { Genomics Research } \\
\text { Institute }\end{array}$ & $\begin{array}{l}\text { Data analysis, data } \\
\text { interpretation, and } \\
\text { manuscript review }\end{array}$ \\
\hline $\begin{array}{l}\text { Ashley L. } \\
\text { Siniard, BS }\end{array}$ & $\begin{array}{l}\text { Translational } \\
\text { Genomics Research } \\
\text { Institute }\end{array}$ & $\begin{array}{l}\text { Acquisition of data, data } \\
\text { interpretation, and } \\
\text { manuscript review }\end{array}$ \\
\hline $\begin{array}{l}\text { Megan Russell, } \\
\text { BS }\end{array}$ & $\begin{array}{l}\text { Translational } \\
\text { Genomics Research } \\
\text { Institute }\end{array}$ & $\begin{array}{l}\text { Data analysis, data } \\
\text { interpretation, and } \\
\text { manuscript review }\end{array}$ \\
\hline $\begin{array}{l}\text { Ryan Richholt, } \\
\text { BS }\end{array}$ & $\begin{array}{l}\text { Translational } \\
\text { Genomics Research } \\
\text { Institute }\end{array}$ & $\begin{array}{l}\text { Data analysis, data } \\
\text { interpretation, and } \\
\text { manuscript review }\end{array}$ \\
\hline
\end{tabular}

Appendix 1 (continued)

\begin{tabular}{|c|c|c|}
\hline Name & Location & Contribution \\
\hline $\begin{array}{l}\text { Matt De Both, } \\
\text { BS }\end{array}$ & $\begin{array}{l}\text { Translational } \\
\text { Genomics Research } \\
\text { Institute }\end{array}$ & $\begin{array}{l}\text { Data analysis, data } \\
\text { interpretation, and } \\
\text { manuscript review }\end{array}$ \\
\hline $\begin{array}{l}\text { Ana M. Claasen, } \\
\text { BS }\end{array}$ & $\begin{array}{l}\text { Translational } \\
\text { Genomics Research } \\
\text { Institute }\end{array}$ & $\begin{array}{l}\text { Data analysis, data } \\
\text { interpretation, and } \\
\text { manuscript review }\end{array}$ \\
\hline $\begin{array}{l}\text { Isabelle } \\
\text { Schrauwen, PhD }\end{array}$ & $\begin{array}{l}\text { Columbia University } \\
\text { Medical Center }\end{array}$ & $\begin{array}{l}\text { Data analysis, data } \\
\text { interpretation, and } \\
\text { manuscript review }\end{array}$ \\
\hline $\begin{array}{l}\text { Stanley F. } \\
\text { Nelson, MD }\end{array}$ & $\begin{array}{l}\text { University of California } \\
\text { Los Angeles }\end{array}$ & $\begin{array}{l}\text { Data interpretation and } \\
\text { manuscript review }\end{array}$ \\
\hline $\begin{array}{l}\text { Matthew J. } \\
\text { Huentelman, } \\
\text { PhD }\end{array}$ & $\begin{array}{l}\text { Translational } \\
\text { Genomics Research } \\
\text { Institute }\end{array}$ & $\begin{array}{l}\text { Data interpretation and } \\
\text { manuscript review }\end{array}$ \\
\hline $\begin{array}{l}\text { David W. Craig, } \\
\text { PhD }\end{array}$ & $\begin{array}{l}\text { Translational } \\
\text { Genomics Research } \\
\text { Institute }\end{array}$ & $\begin{array}{l}\text { Data analysis, data } \\
\text { interpretation, and } \\
\text { manuscript review }\end{array}$ \\
\hline $\begin{array}{l}\text { Kumaraswamy } \\
\text { Sivakumar, MD }\end{array}$ & $\begin{array}{l}\text { Neuromuscular Clinic } \\
\text { and Research Center }\end{array}$ & $\begin{array}{l}\text { Acquisition of data, data } \\
\text { analysis, data } \\
\text { interpretation, and } \\
\text { manuscript review }\end{array}$ \\
\hline $\begin{array}{l}\text { Vinodh } \\
\text { Narayanan, MD }\end{array}$ & $\begin{array}{l}\text { Translational } \\
\text { Genomics Research } \\
\text { Institute }\end{array}$ & $\begin{array}{l}\text { Acquisition of data, data } \\
\text { analysis, data } \\
\text { interpretation, manuscript } \\
\text { writing, and review }\end{array}$ \\
\hline $\begin{array}{l}\text { Sampathkumar } \\
\text { Rangasamy, } \\
\text { PhD }\end{array}$ & $\begin{array}{l}\text { Translational } \\
\text { Genomics Research } \\
\text { Institute }\end{array}$ & $\begin{array}{l}\text { Acquisition of data, data } \\
\text { analysis, data } \\
\text { interpretation, manuscript } \\
\text { writing, and review }\end{array}$ \\
\hline
\end{tabular}

Appendix 2 Coinvestgators

\begin{tabular}{|c|c|c|}
\hline Name & Location & Contribution \\
\hline $\begin{array}{l}\text { Valerie Arboleda, } \\
\text { MD, PhD }\end{array}$ & $\begin{array}{l}\text { University of } \\
\text { California Los } \\
\text { Angeles }\end{array}$ & $\begin{array}{l}\text { Data analysis and data } \\
\text { interpretation }\end{array}$ \\
\hline $\begin{array}{l}\text { Joshua Deignan, } \\
\text { PhD }\end{array}$ & $\begin{array}{l}\text { University of } \\
\text { California Los } \\
\text { Angeles }\end{array}$ & $\begin{array}{l}\text { Data analysis and data } \\
\text { interpretation }\end{array}$ \\
\hline $\begin{array}{l}\text { Naghmeh } \\
\text { Dorrani, MS }\end{array}$ & $\begin{array}{l}\text { University of } \\
\text { California Los } \\
\text { Angeles }\end{array}$ & $\begin{array}{l}\text { Data analysis and data } \\
\text { interpretation }\end{array}$ \\
\hline Emilie Douine, MS & $\begin{array}{l}\text { University of } \\
\text { California Los } \\
\text { Angeles }\end{array}$ & $\begin{array}{l}\text { Data analysis and data } \\
\text { interpretation }\end{array}$ \\
\hline $\begin{array}{l}\text { Marina S. Dutra- } \\
\text { Clarke, MD }\end{array}$ & $\begin{array}{l}\text { University of } \\
\text { California Los } \\
\text { Angeles }\end{array}$ & $\begin{array}{l}\text { Data analysis and data } \\
\text { interpretation }\end{array}$ \\
\hline Celeste Eno, PhD & $\begin{array}{l}\text { University of } \\
\text { California Los } \\
\text { Angeles }\end{array}$ & $\begin{array}{l}\text { Data analysis and data } \\
\text { interpretation }\end{array}$ \\
\hline $\begin{array}{l}\text { Brent Fogel, MD, } \\
\text { PhD }\end{array}$ & $\begin{array}{l}\text { University of } \\
\text { California Los } \\
\text { Angeles }\end{array}$ & $\begin{array}{l}\text { Data analysis and data } \\
\text { interpretation }\end{array}$ \\
\hline
\end{tabular}


Appendix 2 (continued)

\begin{tabular}{|c|c|c|}
\hline Name & Location & Contribution \\
\hline $\begin{array}{l}\text { Wayne W. Grody, } \\
\text { MD, PhD }\end{array}$ & $\begin{array}{l}\text { University of } \\
\text { California Los } \\
\text { Angeles }\end{array}$ & $\begin{array}{l}\text { Data analysis and data } \\
\text { interpretation }\end{array}$ \\
\hline $\begin{array}{l}\text { Sung-Hae Kang, } \\
\text { PhD }\end{array}$ & $\begin{array}{l}\text { University of } \\
\text { California Los } \\
\text { Angeles }\end{array}$ & $\begin{array}{l}\text { Data analysis and data } \\
\text { interpretation }\end{array}$ \\
\hline $\begin{array}{l}\text { Jessica Kianmahd, } \\
\text { MS }\end{array}$ & $\begin{array}{l}\text { University of } \\
\text { California Los } \\
\text { Angeles }\end{array}$ & $\begin{array}{l}\text { Data analysis and data } \\
\text { interpretation }\end{array}$ \\
\hline Hane Lee, PhD & $\begin{array}{l}\text { University of } \\
\text { California Los } \\
\text { Angeles }\end{array}$ & $\begin{array}{l}\text { Data analysis, data } \\
\text { interpretation, and } \\
\text { manuscript review }\end{array}$ \\
\hline $\begin{array}{l}\text { Julian A. Martinez- } \\
\text { Agosto, MD, PhD }\end{array}$ & $\begin{array}{l}\text { University of } \\
\text { California Los } \\
\text { Angeles }\end{array}$ & $\begin{array}{l}\text { Data analysis and data } \\
\text { interpretation }\end{array}$ \\
\hline $\begin{array}{l}\text { Jaclyn Murphy, } \\
\text { PhD }\end{array}$ & $\begin{array}{l}\text { University of } \\
\text { California Los } \\
\text { Angeles }\end{array}$ & $\begin{array}{l}\text { Data analysis and data } \\
\text { interpretation }\end{array}$ \\
\hline $\begin{array}{l}\text { Stanley F. Nelson, } \\
\text { MD }\end{array}$ & $\begin{array}{l}\text { University of } \\
\text { California Los } \\
\text { Angeles }\end{array}$ & $\begin{array}{l}\text { Data interpretation and } \\
\text { manuscript review }\end{array}$ \\
\hline $\begin{array}{l}\text { Fabiola Quintero- } \\
\text { Rivera, MD }\end{array}$ & $\begin{array}{l}\text { University of } \\
\text { California Los } \\
\text { Angeles }\end{array}$ & $\begin{array}{l}\text { Data analysis and data } \\
\text { interpretation }\end{array}$ \\
\hline $\begin{array}{l}\text { T. Niroshi } \\
\text { Senarate, PhD }\end{array}$ & $\begin{array}{l}\text { University of } \\
\text { California Los } \\
\text { Angeles }\end{array}$ & $\begin{array}{l}\text { Data analysis and data } \\
\text { interpretation }\end{array}$ \\
\hline
\end{tabular}

\section{References}

1. de Souza PVS, Batistella GN de R, Lino VC, de Rezende Pinto WBV, Annes M, Oliveira ASB. Clinical and genetic basis of congenital myasthenic syndromes. Arq Neuro-Psiquiatr 2016;74:750-760.
2. Senderek J, Müller JS, Dusl M, et al. Hexosamine biosynthetic pathway mutations cause neuromuscular transmission defect. Am J Hum Genet 2011;88:162-172.

3. Rodríguez Cruz P, Palace J, Beeson D. The neuromuscular junction and wide heterogeneity of congenital myasthenicsyndromes. Int J Mol Sci 2018;19:1677-1723.

4. Engel AG, Shen XM, Selcen D, Sine SM. Congenital myasthenic syndromes: pathogenesis, diagnosis, and treatment. Lancet Neurol 2015;14:420-434.

5. Guergueltcheva V, Müller JS, Dusl M, et al. Congenital myasthenic syndrome with tubular aggregates caused by GFPT1 mutations. J Neurol 2011;259:838-850.

6. Dusl M, Senderek J, Müller JS, et al. A 3'-UTR mutation creates a microRNA target site in the GFPT1 gene of patients with congenital myasthenic syndrome. Hum Mol Genet 2015;24:3418-3426.

7. Helman G, Sharma S, Crawford J, et al. Leukoencephalopathy due to variants in GFPT1-associated congenital myasthenic syndrome. Neurology 2019;92:e587-e593.

8. Schrauwen I, Szelinger S, Siniard AL, et al. A de novo mutation in TEAD1 causes nonX-linked aicardi syndrome. Invest Ophthalmol Vis Sci 2015;56:3896-3904.

9. Lee $\mathrm{H}$, Deignan JL, Dorrani N, et al. Clinical exome sequencing for genetic identification of rare mendelian disorders. JAMA 2014;312:1880-1916.

10. Lek M, Karczewski KJ, Minikel EV, et al; Exome Aggregation Consortium. Analysis of protein-coding genetic variation in 60,706 humans. Nature 2016;536:285-291.

11. Li MM, Datto M, Duncavage EJ, et al. Standards and guidelines for the interpretation and reporting of sequence variants in cancer: A Joint Consensus Recommendation of the Association for Molecular Pathology, American Society of Clinical Oncology, and College of American Pathologists. J Mol Diagn 2017;19:4-23.

12. Park YE, Shin JH, Kang B, Lee CH, Kim DS. NEB-related core-rod myopathy with distinct clinical and pathological features. Muscle Nerve 2016;53:479-484.

13. Engel AG. Congenital myasthenic syndromes in 2018. Curr Neurol Neurosci Rep 2018;18:46.

14. Selcen D, Shen XM, Milone M, et al. GFPT1-myasthenia: clinical, structural, and electrophysiologic heterogeneity. Neurology 2013;81:370-378.

15. Yis U, Becker K, Kurul SH, et al. Genetic landscape of congenital myasthenic syndromes from Turkey: novel mutations and clinical insights. J Child Neurol 2017;32: 759-765.

16. DeHaven JE, Robinson KA, Nelson BA, Buse MG. A novel variant of glutamine: fructose-6-phosphate amidotransferase-1 (GFAT1) mRNA is selectively expressed in striated muscle. Diabetes Am Diabetes Assoc 2001;50:2419-2424.

17. Cossins J, Belaya K, Hicks D, et al. Congenital myasthenic syndromes due to mutations in ALG2and ALG14. Brain 2013;136:944-956.

18. Klein A, Robb S, Rushing E, Liu WW, Belaya K, Beeson D. Congenital myasthenic syndrome caused by mutations in DPAGT. Neuromuscular disorders. Neuromuscul Disord 2015;25:253-256.

19. Bauché S, Vellieux G, Sternberg D, et al. Mutations in GFPT1-related congenital myasthenic syndromes are associated with synaptic morphological defects and underlie a tubular aggregate myopathy with synaptopathy. J Neurol 2017;264:1791-1803.

20. Zoltowska K, Webster R, Finlayson S, et al. Mutations in GFPT1 that underlie limbgirdle congenital myasthenic syndrome result in reduced cell-surface expression of muscle AChR. Hum Mol Genet 2013;22:2905-2913. 


\section{Neurology

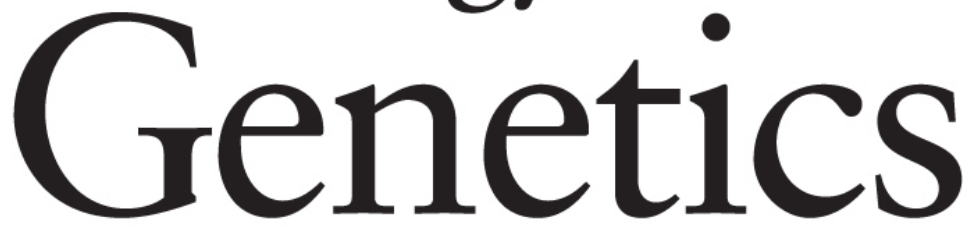

Congenital myasthenic syndrome caused by a frameshift insertion mutation in GFPT1 Szabolcs Szelinger, Jonida Krate, Keri Ramsey, et al. Neurol Genet 2020;6;

DOI 10.1212/NXG.0000000000000468

This information is current as of June 30, 2020

\section{Updated Information \& Services}

References

Subspecialty Collections

Permissions \& Licensing

Reprints including high resolution figures, can be found at: http://ng.neurology.org/content/6/4/e468.full.html

This article cites 20 articles, 0 of which you can access for free at: http://ng.neurology.org/content/6/4/e468.full.html\#\#ref-list-1

This article, along with others on similar topics, appears in the following collection(s):

EMG

http://ng.neurology.org//cgi/collection/emg

Muscle disease

http://ng.neurology.org//cgi/collection/muscle_disease

Myasthenia

http://ng.neurology.org//cgi/collection/myasthenia

Information about reproducing this article in parts (figures,tables) or in its entirety can be found online at:

http://ng.neurology.org/misc/about.xhtml\#permissions

Information about ordering reprints can be found online: http://ng.neurology.org/misc/addir.xhtml\#reprintsus

Neurol Genet is an official journal of the American Academy of Neurology. Published since April 2015, it is an open-access, online-only, continuous publication journal. Copyright Copyright $\odot 2020$ The Author(s). Published by Wolters Kluwer Health, Inc. on behalf of the American Academy of Neurology.. All rights reserved. Online ISSN: 2376-7839.

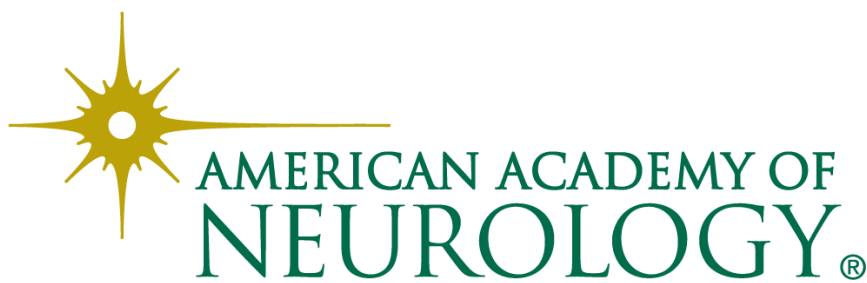

